\title{
The prevalence of primary headache and its association with socioeconomic factors among school children in Lithuania
}

\author{
A Januskeviciene*, A Zaborskis, E Vaitkaitiene \\ From The European Headache and Migraine Trust International Congress \\ London, UK. 20-23 September 2012
}

\section{Objective}

The aim of this study was to estimate the prevalence of headache among children in Lithuania in 2010 and describe the association between headache and socioeconomic factors. This study was a part of the CrossNational Survey on Health Behaviour in School-aged Children - World Health Organization Collaborative Study (HBSC).

\section{Methods}

The research was carried out according to the methodology of the HBSC study using the anonymous standardized questionnaire. In total, 5,323 students (2, $740(51.5 \%)$ boys and 2,583 (48.5\%) girls aged 11, 13 and 15 years from Lithuania were surveyed in the 2010 school-year.

\section{Results}

The total prevalence of frequent headache (at least once a week) among children 11, 13 and 15 years of age was $33,7 \% 31,9 \%$ and $34,4 \%$, respectively. Pain was most frequent among older girls (13 and 15 years of age $)(\chi 2=$ $43,529 ; \mathrm{df}=2 ; \mathrm{p}<0.005)$. The headache prevalence was slightly higher in low-income families and divorsed or one parent families compared to those of high status and two parent families. Multivariate analysis revealed that having a good relationship with parents and peers, associated with less headache cases.

\section{Conclusion}

Headache is more common among children with lower socioeconomic groups. Social causation can play a role in

Lithuanian University of Health Science, Lithuania, Institute for Biomedical Research of Kaunas University of Health Science, 4, Eiveniu str., Kaunas, LT50009, Lithuania

\section{SpringerOpen ${ }^{\circ}$}

the pathogenesis of headache and should be considered by health promoters.

Published: 21 February 2013

Reference

1. Currie C, Hurrelmann K, Settertobulte W, Smith R, Todd J: Health and health behaviour among young people: health behaviour in schoolaged children: a WHO crossnational study (HBSC), international report. Copenhage: $\mathrm{WHO} ; 2000$.

doi:10.1186/1129-2377-14-S1-P3

Cite this article as: Januskeviciene et al:: The prevalence of primary headache and its association with socioeconomic factors among school children in Lithuania. The Journal of Headache and Pain 2013

14(Suppl 1):P3.
Submit your manuscript to a SpringerOpen ${ }^{\circ}$ journal and benefit from:

- Convenient online submission

- Rigorous peer review

- Immediate publication on acceptance

- Open access: articles freely available online

- High visibility within the field

- Retaining the copyright to your article

Submit your next manuscript at $>$ springeropen.com 